\title{
Butterfly fauna of Biratnagar, Nepal
}

\author{
Bharat Raj Subba ${ }^{\mathbf{1}}$ and Jawan Tumbahangfe ${ }^{\mathbf{2}}$ \\ ${ }^{I}$ Birat Campus, School of Science and Technology, Biratnagar, Nepal \\ ${ }^{2}$ Punya HSS, Rajarani, Dhankuta, Nepal
}

\begin{abstract}
A total 31 species of butterfly belonging to 26 genera under six families were reported from Biratnagar, Nepal. Specimens were collected during March to June in 2015.
\end{abstract}

Key words: Butterfly, Biratnagar.

\section{Introduction}

Butterflies are the most interesting colourful arthropods of great natural aesthetic value. Along with gradual habitat shrinkage due to anthropogenic activities, the population of butterflies and their species are also decreasing accordingly. In spite of its great economic value, less attention has been paid to the conservation of butterfly. Emergence of different butterfly species depends on availability of flowering vegetation humidity to some extent and mostly it follows season, climatic condition and weather. The study of butterfly of any place and season is really pleasing activity for nature lovers and conservationists.

\section{Study site}

Biratnagar sub-metropolis (Lat. 26029', Long. 087 $16^{\prime}$ ') was selected for the present study of the butterflies is the largest industrial town next to the capital city Kathmandu. It has stretched over $760 \mathrm{sq} \mathrm{m}$ in Morang district. Tropical climate prevails here. Butterflies are seen everywhere such as agricultural lands, gardens, open lands. Workers on butterflies have made contributions to butterflies of Nepal but their works belong to mainly central and western Nepal. Reports of butterlies form eastern Nepal is scanty. Regarding works on butterflies of Nepal special mention can be made for the works of (Khanal, 1987; Shrestha \& Smith, 1977; Smith, 1981-82; Smith, 1989; Smith, 1984; Subba, 2005; Thapa \& Bhusal, 2009)

\section{Materials and Methods}

Butterfly net was used to catch butterflies. They were safely kept in paper envelopes in wing folded state taking care so that their antennae and wings might not get damaged. Napthalin balls were used to preserve them from fungal infection and attack of mites. The collected butterflies were identified with the help of books on butterflies (Smith, 1994).

\section{Results and Discussion}

There might appear more butterfly species in other months. This report includes number of butterflies observed and collected from March to June 2015 only. Altogether 38 species of butterfly belonging to 30 genera under six families were reported..

As Biratnagar metropolis is swelling due to unmanaged and unplanned urbanization, industrialization and land use pattern, butterfly diversity seems to have been decreasing. The most of the natural habitats such as river banks, ponds, paddy fields, gardens and meadows etc. are being engulfed by pollution. In this condition, every wildlife is facing a critical environment for their normal life to lead. Because of habitat destruction by human activities and impact of climate change, the expected number of butterfly did not turn out. There might several other 
reasons besides mentioned above which are directly or indirectly in the decline of butterflies' population. If people will not consider butterflies as an important component of an ecosystem to which human themselves belong, in the time to come, smaller number of species may turn out. This present survey definitely has reached a solid finding is that the population of the has decreased due to increased urban area and decreased agricultural lands.

List of butterflies

Family: Danaidae

Danaus genutia (Cramer1779 Danaus chryssipus (Linnaeus 1758)

Parantica aglea (Stroll 1781) Parantica melanius(Gramer 1857)

Euploea core (Gramer,1780)

Euploea mulciber (Gramer 1777)

Family: Satyridae

Melanitis leda (Linnaeus 1758)

Nemetis mekara(Moore 1857)

Melanitis zitenius( Herbst 1796)

Precis lemonias (Linnaeus, 1758)

Family: Nymphalidae

Cupha erymanthis (Billberg 1820) Vagrans egista (Hamming 1934)

Vanessa sp.(Fabricius 1807) Phalanta phalantha(Horsfield 1829)

Aglais cashmirensis(Dalman1916) Kalima sp.(Doubleday 1849)

Family: Pieridae

Pieris canidia indica (Sparman768)

Delias pasithoe (Hubner1819)

Catopsilia pyranthe pyranthe (Linnaeus1758)

Eurema hecabe (Moore 1886)

Catopsilia pomona pomona (Fabricus775)

Family: Papilionidae

Leptosia nina (Hubner 1818)

Pachliopta aristochiae (Reakirt 1865)

Family: Lycaenidae

Taraka hamada (Doherty 1889)

Heliophorus epicles(Geyer 1832)

Arhopala sp.(Boisduval 1832)

Jamides sp.(1819 Hubner)

Nacaduba kurava (Moore 1881)

Freyeria sp.(Couvoisier 192)

Zizeeria sp. ( Capman 1920)

\section{Acknowledgements}

Sincere thanks go to Neela Subba, Jyoti Karna, Kalpana Shrestha and Mr. Bipul Bhujel Subba for helping us during collection of butterflies from different places of Morang district

\section{References}

Khanal, B. 1987. Butterflies in Pokhara-Muktinath Trek. J.Nat.Hist.Mus. 11(1-4)

Shrestha, P.K. \& C. Smith 1977. Varitation among Nepal's Butterflies J.Nat.Hist.Mus, 1(2-4)

Smith, C. 1978. Scientific list of Nepals Butterflies. J.Nat.Hist.Must. 2(3): 127-182.

Smith, C. 1981-82. Butterflies. In Wild is Beautiful (ed. T.C. Majupuria) published by S. Devi, Lalitpur colony, Gwalior India.

Smith, C. 1989. Some butterflies of Western Nepal part II. Pre and post monsoon butterflies. J.Nat.Hist.Mus. 4(2)

Smith, C. 1994. Butterflies of Nepal (2 ${ }^{\text {nd }}$ edition). Majupuria Publication, Craftsman Press. Bangkok, Thailand, 368p.

Subba, B.R. 2005. A checklist of Butterlies of Gajurmukhi Village Development Committee, Ilam District, Eastern Nepal. J.Nat.Hist.Mus. 22: 38-40.

Thapa, G. \& D.R. Bhusa 2009.Species diversity and seasonal vaviation of Butterly fauna in Thankot and Syuchatar VDC of Kathmandu valley. J.Nat.Hist.Mus.24: 9-15. 